\title{
骨転移を初発とした癌症例について
}

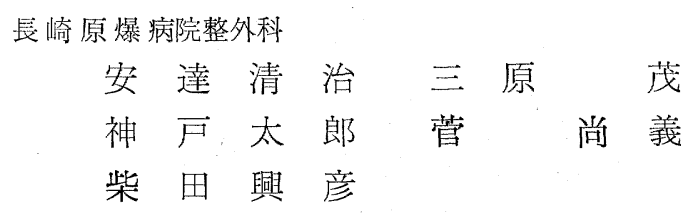

\section{Observation on the Cancer Patients with Skeletal Metastasis which was the Initial Sign of the Cases}

By

\author{
K. Adachi, S. Mihara, T. Kanbe, \\ T. Suga \& O. Shibata \\ Depertment of Orthpedic Surgery \\ Nagasaki Atomic Bomb Haspital
}

Fifteen cases of cancer patients with skeletal metastasis as the initial sign were reported.

Among them, 5 cases have their primary site in bronchus, 2 in Prostate, 2 in liver and 1 in stomach respectively. And in remaining 3 cases, we could not find their primary site in spite of the clinical, cytogical and autoptical examination. Bicides, We are now examining their primary site in 2 cases.

We also reported 2 cases of the skeletal metastasis of hepatom which were diagnosed by necropsy.

癌の骨転移症状が先行し，原発巣が無症状に経過す る場合，しばしば他㷝患之間違って取り扱われ，早期 彰断，乙とに原発巣の早期発見の機を失する伦険があ ることに注意しなければならない，我々はこのたび， 骨転移を初発症状とした癌患者15例住さ，いささか の検討を試みたので報告する.
原発巣については（表 1 ), 15 例中, 肺癌 5 例, 前 立腺癌 2 例, 肝癌 2 例, 胃癌 1 例, 原発巣不明 3 例, 現在検索中 2 例である.肺癌の特に多いのは諸家の報 告々同様である. 原発巣不明の 3 例は, いつれむ生検 にて未分化な像を呈しており, 可能性のある諸喴器を 検索したが, その決定が不能であった。

表 1

\begin{tabular}{|c|c|c|c|c|c|c|c|}
\hline 症 & 例 & 性 & 年令 & 初 㡣 時 主 訴 & 初診時転移骨 & 原 発 巣 & 予後 \\
\hline $\begin{array}{r}1 \\
2 \\
3 \\
4 \\
5 \\
6 \\
7 \\
8 \\
9 \\
10 \\
11 \\
12 \\
13 \\
14 \\
15\end{array}$ & $\begin{array}{ll}\text { A. } & \text { A. } \\
\text { S. } & \mathrm{N} . \\
\text { Y. } & \mathrm{U} . \\
\text { M. } & \mathrm{K} . \\
\text { R. } & \mathrm{S} . \\
\mathrm{K} . & \mathrm{E} . \\
\mathrm{T} . & \mathrm{N} . \\
\mathrm{K} . & \mathrm{H} . \\
\mathrm{Y} . & \mathrm{K} . \\
\mathrm{Y} . & \mathrm{S} . \\
\mathrm{K} . & \mathrm{W} . \\
\mathrm{H} . & \mathrm{N} . \\
\mathrm{K} . & \mathrm{Y} . \\
\mathrm{T} . & \mathrm{S} . \\
\text { J. } & \mathrm{K} .\end{array}$ & $\begin{array}{l}\text { 男 } \\
\text { 男 } \\
\text { 男 } \\
\text { 男 } \\
\text { 女 } \\
\text { 男 } \\
\text { 男 } \\
\text { 男 } \\
\text { 男 } \\
\text { 男 } \\
\text { 男 } \\
\text { 男 } \\
\text { 男 } \\
\text { 男 } \\
\text { 男 }\end{array}$ & $\begin{array}{l}68 \\
59 \\
52 \\
45 \\
72 \\
72 \\
55 \\
72 \\
42 \\
68 \\
62 \\
60 \\
67 \\
75 \\
58\end{array}$ & 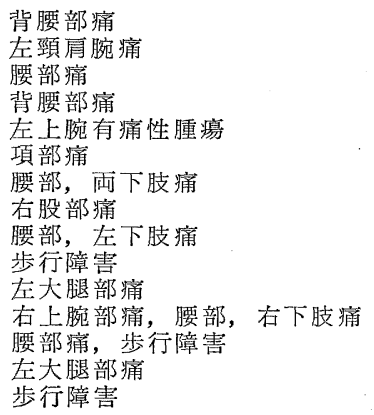 & 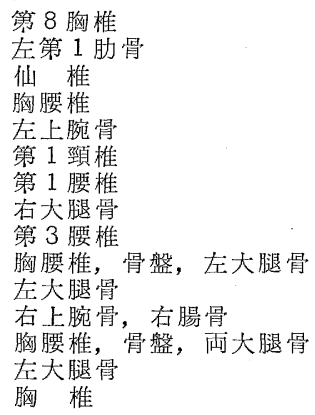 & 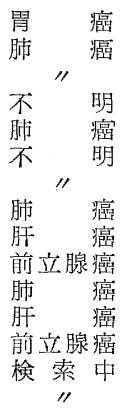 & $\begin{array}{c}\text { 死亡 } \\
\text { " } \\
\text { " } \\
\text { " } \\
\text { " } \\
\text { " } \\
\text { " } \\
\text { " } \\
\text { 生存 } \\
\text { 死亡 } \\
\text { 生存 } \\
\text { " } \\
\text { " }\end{array}$ \\
\hline
\end{tabular}




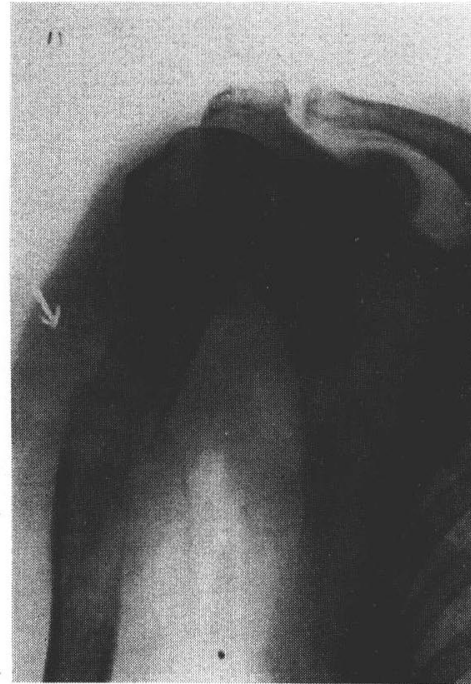

図 160 才男子

上腕骨病的骨折(原発性肝癌転移例)

年令については, 最低 42 才, 最高 75 才, 平均年令 61.8 才である. 全例が 40 才台以上で, 所謂癌の好発 年令に含まれる.

性別に関しては，男性14 例に対し，女性はわづか 1 例のみであった。此様に著しい格差がみられたの は，症例数が少いためにあよるが，女性の癌腫の中 で, 高位を占める乳癌及び子宮癌等が, 骨転移症状を 呈する以前に，比較的早期に診断がつき，治療がなさ れるためによるあのよも考えられる.

初診時症状としては，疼痛を主訴として受診したも のが 8 例之最も多く，次いで病的骨折が 4 例，排尿便 障害及び歩行障害等の脊髄症状を主よするもの 3 例で ある. 興味あるのは前立腺癌転移の 2 例が，いづれあ 疼痛及び知覚障害の出現後, 急激に歩行障害や膀胱直 腸障害を来したととである，骨転移率の最も高い前立 腺癌でも, 特に腰椎は骨盤骨之共に転移好発部位であ る. 得津はかかる如き症例に対し, Schmor1-Junghanns の云う osteophytosis carcinomatosa が，椎 管或は椎間孔で増殖し，脊䯣等を圧迫する結果，かか る症状を惹起するものと推定している。

初診時転移骨としては, 脊椎 9 例, 大腿骨 5 例, 上 腕骨 2 例, 骨盤骨 2 例, 肋骨 1 例であり, 脊椎が最む 多いのは諸家の統計と一致するところである，脊椎転 移部位では, 莖頁椎 1 例, 胸椎 5 例, 腰椎 5 例, 仙椎 1 例で,やはり胸腰椎に多発している. またレ線上脊椎

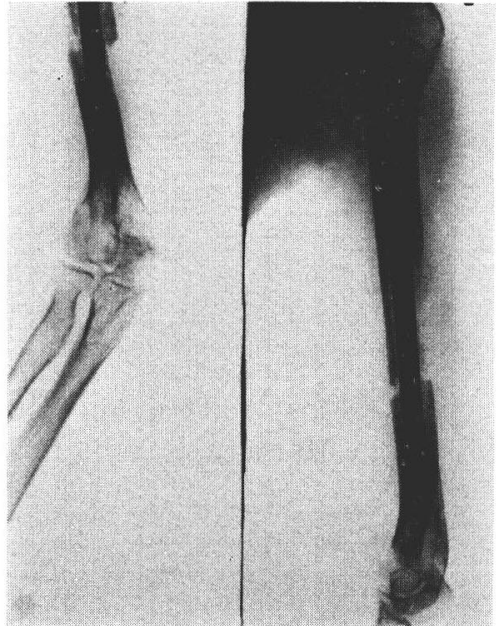

図272才 女性 上腕骨病的骨折（肺癌転移例）

に孤立性に転移せるもの 5 例，多発性のものが 4 例で あった。

原発巣が不明で, 孤立性に転移がみられる場合, 乙 とによっては単なる Osteoporosis か, 圧迫骨折か, 或はカリエスか等と診断に迷うことがある．前山は脊 椎転移の初期像として, 椎体上線の陥凹及び椎体前縁 の軽度の突出を指摘し, 菊屋は椎体は扁平かつ横径を 増して潰れることが多く, 従って龟背を作ることは少 い上述へ，脊椎病的骨折 23 例中楔状を呈したものは 1 例むなかったと報告している。しかしいづれにせ よ, レ線の読影にかなりの困難を伴う場合があるとと は事実であり，確信のあてない場合は，後日かならず 再撮影を行い，検討するだけの慎重さが必要である う.

次にレ線像に関しては，前立腺癌による 2 例を除い ては，殆んど Osteolytic な像を呈しており，そのう ち長管骨に転移を来した 7 例中 4 例は殆んど外傷らし き機転なく骨折を起したあのであり，ここにあ骨転移 癌としての特長がうかがえる.

予後については，症状発現時期を骨転移時期之考 え, その生存期間を調べてみると, 死亡群では最長 1 年, 最短は 2 ケ月で, 平均 7.4 ケ月である. 生存群 4 例中 2 例は前立腺癌患者で, とむに 1 年を過ぎ, 現在 経過観察中である.

次に比較的稀れとされている原発性肝癌の骨転移例 について述べる。 
症例 142 才男子

家族歴：特記事項なし

既往歴：昭和 42 年 1 月より罝潰演にて治療中.

主訴: 腰痛, 臀部上り左下肢放散痛.

現病歴：昭和 42 年 7 月 27 日急に言語障害が岀現 し，近医で高血圧を指摘され自宅療養をしていた。同 年 7 月 31 日洗面㭙, 水道栓のコックをひねったとき 腰をクッしし, 以来腰痛及び左下肢痛が出現し, 9 月 4 日当科を受診す。

入院時現症：体格栄養中等度, 眼球結膜正常, 胸部 異常なし, 腹部平坦, 腹水 (一), 肝右季肘下部一横指 触知軽度圧痛尚り，脾 (一), 検查所見: 尿便血液異 常なし, 総蛋白量 $7.0 \mathrm{~g} / \mathrm{dl}$, T.T.T. 5.7, Zn. T.T. 11.3 , 黄㾝指数 3 , コレステロール $226 \mathrm{mg} / \mathrm{dl}$ al-pase $3 . \mathrm{Bu}$, a cid-p $\left\{\begin{array}{l}\mathrm{T}=2.2 \mathrm{~K} \mathrm{~A} \\ \mathrm{P}=0.2 \mathrm{~K}\end{array}\right.$, 腎機能検査 異常 なし，

初䧐時腰椎単純レ線では第 3 腰椎左側椎马根部が稍 々不鮮明である以外著変なく, 腰部椎間板障害の診断 で経過観察していたが，3週間後のレ線所見では，第 3 腰椎马根部の破壊消失がみられ，またミエログラフ ィーでは第 2 腰椎下縁にて完全ブロックを呈した. 10 月 3 日手術施行. 組織検査では Metastatic Carcinoma であるが，原発栄は不明と云う診断であった。 その後種々検査を行ったが原発巣はつい発見されな いまま, 翌 43 年 2 月 28 日死亡. 剖検の結果, 肝硬変 を伴った原発性肝癌の診断を得た。

症例 260 才男子

家族歴，既往歴：特記事項なし.

主訴：右下肢, 右上腕, 背部神経痛様疼痛.

現病歴：昭和 33 年 9 月より 慢性肝炎にて 治療を受 けていたが, 昭和 39 年夏頃より, 右肩胛部より上腕 にか汁て疼痛あり，同年 12 月頃よりさらに右留部よ り右下肢に神経痛様疼痛を来し, 近医にて坐骨神経痛 の治療を受けていたが，右下肢痛は次第に増強し，歩 行困難となり，昭和 40 年 6 月 18 日当科受揨す.

入院時現症: 体格栄養中等度, 眼球結膜正常胸部異 常なし, 腹部平坦腹水 (一), 肝右季肋下部 2 横指触 知, 硬度増強圧痛なし, 脾 (一).

検查所見: 尿便血液異常なし, 総蛋白量 $7.0 \mathrm{~g} / \mathrm{d} 1$ alb 38.4\%,r-g1 28.4\%, A/G 0.63, T.T.T. 10.7, Zn. T.T., 21.4, コレステロール $275 \mathrm{mg} / \mathrm{dl}$, GOT 113, GPT 44, al-p-ase 3. Bu, EKG 異常なし. 初診時レ線所見で, 右上腕骨及び右腸骨部に溶骨性
の転移像がみられ，胸骨穷刺及び上腕骨の生検によ り, 癌転移像を認めたが, 原発巣検索中, 同年 8 月 2 日悪液質にて死亡．剖検により肝硬変を伴った肝癌で あること老確認した。

原発性肝癌の骨転移率については Charache は 1125 例中 18 例 $1.6 \%$, 菊屋は 110 例中 2 例 $1.8 \%$, 貴家は 110 例中 16 例 $14.5 \%$ ，前山は 34 例中 4 例 10.3\%と，それぞれ報告者によりかなりの差がみら れるが，乙れは症例数の寡多，病理統計と呫床統計と の違いなどの条件により左右されるが，我々も小数例 ではあるが 15 例中 2 例 $13 \%$ とかなりの率にみられ た.

原発性肝癌は多彩な臨床症状を呈し，特異な症状の ないため，確定診断をつけるには困難を伴うことが多 く，臨床的に看過され易い上屯考えられる，加かる 点, 骨転移癌の原発巣追求には，原発性肝癌も常に考 慮に入れて扔く必要があろう。

以上我々は骨転移症状が先行した癌患者, 15 例に つきいささかの検討を試みたので報告した。

\section{参 考 文 献}

1) 前山：整形外科. $17: 950,1966$.

2) 前山：整形外科と災害外科, $16: 127$, S. 42 .

3) 得津: 整形外科. $14: 868,1963$.

4) 伊丹: 骨腫癔, 医学書院, 1966.

5) 鶴田：中部日本整形外科. $11: 980$, S. 43.

6) 後藤：中部日本整形外科. 9, 868, 1963.

7) 竹内: 整形外科. $20: 398,1969$.

8）北川：癌の臨床. $11: 540,1965$.

9) 高橋：外科. 30,217, S. 43.

10) Lichtenstein, L.: Bone Tumors, 3rd ed. 331, the C. V. Mooby, 1956.

\section{追 加 九大整形外科 竹光 義治} 原発巣不明の悪性腫湟転移を疑った症例に我々は S. 42 発表した横断面作図法による椎体の Trephine Biopsy を行なっている. 成功率は $90 \%$ 以上である. 最近，レントゲンテレビを用いるととが普及している が，乙の場合も作図をして执いた方がより安全で早 い，乙れまで穿刺した 33 例中 約半数は悪性腫瘍であ った. 組織所見から原発巣が発見されたことも少なく ない.

最近, 椎体巣の組織診と血管造影所見から Gravitz 腫湯が発見された例がある。 
追 加別府整肢園 佐藤 三郎

私，国立がんセンター時代に本演題と同様の検討を 致しましたが，国立がんセンターであ，やはり，肺が
んが最も多く，ついで腎がん，甲状腺がんおよび前立 腺がん等が主として骨転移を初発症状としおりまし た。

\title{
切除せる躯幹骨悪性腫瘍の3 例
}

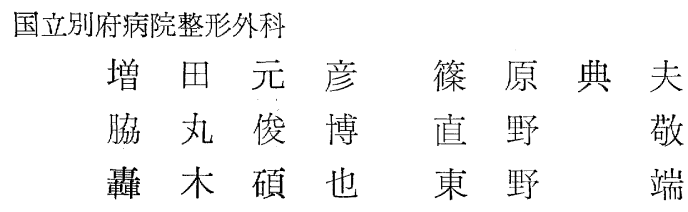

\section{Local Resection of Malignant Lesions of the Scapula and Pelvis}

By

\author{
M. Masuda, N. Shinohara, T. Wakimaru,
} T. Naono, S. Todoroki \& H. Tohno

Department of Orthopedic Surgery, National Beppu Hospital,

Recently, we had an opportunity to perform the wide block resection of the affected bone in three cases of chondrosarcoma originated in the scapula and pelvis.

In these three cases, it was found that the histological findings were well differentiated.

Concernning to the case originating in the scapula, we succeeded in the total resection of the tumor including the sourounding muscles. There are no evidence of local recurrence and shoulder joint retains moderate range in motion.

Concernning to the case originating in the pubis and ischium proliferating of the tumor in the pelvic cavity and adhesion to the intra-pelvic organs were remarkably seen. And, it was thought that total resection of the tumor was difficult.

So that, post-operative Tele-Cobalt irradiation therapy is now being performed.

Cocernning to the case originating in the iliac bone, the iliac wing was resected including the affected area. And, we could recognize several cartilage foci on the cut surface. It is suggested that the tumor is a secondary chondrosarcoma caused by the malignant change of the cartilage foci. So that, it is thought we should look out for malignant change of the remainning cartilage foci.

骨に発生した肉腫の治療に扔いて, 肉腫の治療即ち 切断あるいは離断之公式的飞考えて行われるとき，あ る肉腫にはこの様な治療が過大にすぎることがあり， 広範切除術が最あ適当な治療であるととがある。この 治療で最も良く治療され得る肉腫の一つは分化型の軟 骨肉腫である，我々は最近躯幹骨に発生した軟骨肉腫 に罹患骨の部分切除を行い治療した。

第 1 例 45 才，男，来院の 3 ケ月前に 左肩甲骨部
の腫瘤形成に気付き，当時無痛性であったあのが，来 院の頃には左上肢の運動に際し疼痛を感ずる様になっ た．腫瘤は肩甲骨之共に動く，硬い手拳大の，境界明 膫なむので, 皮覤之の癒着なく, 局所発赤, 熱感む みられない, 病巣部の切除は Phelps の法に従い, 腫

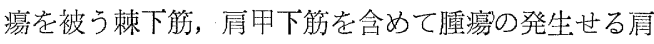
甲骨体部を切除した。堙演は肩甲骨を摤み，その前後 に增殖し，被膜にてよく包被され，淡黄色ないし青白 